Hikmah: Journal of Islamic Studies, 17 (2), 2021, 135-148

http://journal.uinjkt.ac.id/index.php/HIKMAH

DOI: 10.47466/hikmah.v17i1.201. | P-ISSN. 2088-2629, E-ISSN. 2581-0146

\title{
MENGGALI POTENSI ANAK DALAM PENDIDIKAN ISLAM
}

\author{
Hairun Hasanah Sagala \\ Universitas Islam Negeri Sunan Kalijaga Yogyakarta, Indonesia \\ hairunhasanah8@gmail.com
}

\begin{abstract}
Every child is born with a state of purity and nature. This means that children are born in a weak state when in fact they have great potential. But that does not mean that every child is born like a white paper that has not been tarnished, as John Lock argues, and in the Jabariyah view, which considers helpless. This ability assumes that humans have the potential in the form of certain desires related to various types and levels of logical, mental and psychological abilities. Therefore education is needed as a means for the possibilities that exist in individuals for growth and development in accordance with the nature of their creation. How to educate children in Islam, namely; (1) Teach monotheism sentences, (2) attach a good name, (3) train children to pray and provide separate beds for men and women, (4) teach your children to love the Prophet. experts in captivity and reading the Qur'an Therefore, the educational process that meets the needs of nature must be started immediately. This is where the importance of family education by parents. So, in the end, Muslims will be the best of people.
\end{abstract}

Keywords: Potential; Children; Islamic Education; Hadith

\begin{abstract}
Abstrak
Setiap anak terlahir dengan keadaan suci dan fitrah. Artinya anak dilahirkan dalam keadaan yang lemah padahal sebenarnya memiliki potensi yang besar. Tapi itu tidak berarti setiap anak dilahirkan seumpama bagaikan kertas putih yang belum ternodai, seperti pendapat oleh John Lock, dan dalam pandangan jabariyah yang menganggap tak berdaya. Kemampuan ini menganggap bahwa manusia memiliki potensi berupa keinginankeinginan tertentu yang berkaitan dengan berbagai jenis dan tingkat kemampuan logis, mental dan psikologis. Oleh karena itu pendidikan diperlukan sebagai sarana Untuk kemungkinan yang ada pada individu untuk pertumbuhan dan perkembangan sesuai dengan fitrah ciptaannya. Cara mendidik anak dalam Islam yaitu; (1) Mengajarkan anak kalimat Tauhid, (2) Menyematkan nama yang baik, (3) Menlatih anak agar mau melaksanakan sholat dan Menyediakan Tempat Tidur Terpisah antara Laki-laki dan Perempuan, (4) Ajarkan anak-anakmu untuk mencintai Nabi. ahlinya dalam penangkaran dan membaca Al-Qur'an Oleh karena itu, proses pendidikan yang memenuhi kebutuhan fitrah harus segera dimulai. Di sinilah pentingnya pendidikan keluarga oleh orang tua. Sehingga, pada akhirnya, umat Islam akan menjadi sebaik-baik umat.
\end{abstract}

Kata Kunci: Potensi; Anak; Pendidikan Islam; Hadis 


\section{PENDAHULUAN}

Berbicara tentang kemanusiaan sudah ada sejak lama dan terus berlanjut hingga saat ini. Pemikiran mengenai kemanusiaan tidak akan pernah selesai. Saat ini orang yang mempelajari sesuatu di luar angkasa adalah bagian yang sangat penting. Penjelasan ini mengungkap potensi apa yang dimiliki manusia serta perannya di alam semesta. Dalam Islam, fitrah manusia adalah gabungan dari tubuh. ${ }^{1}$

Setiap orang juga memiliki tujuan pendidikan yang beranekaragam. Dengan begitu dapat dilihat dari tujuan, kebutuhan, dan keinginan seseorang tersebut. Maka pendidikan menjadi hal yang cukup penting setiap kehidupan, dan merupakan kebutuhan dasar semua orang. Keberhasilan pendidikan, baik formal maupun informal, memiliki dampak yang signifikan terhadap tatanan masyarakat dan standar hidup.

Terdapat dalam Islam juga mengajarkan anak tidak terlahir hanya sebagai penerus orangtuanya ataupun sebagai penerus keturunan, tetapi anak mempunyai fungsi atau asset bagi orangtua yang kelak akan menjadi modal ataupun penolong di akhirat nanti. Di dalam hadist juga dijelaskan:

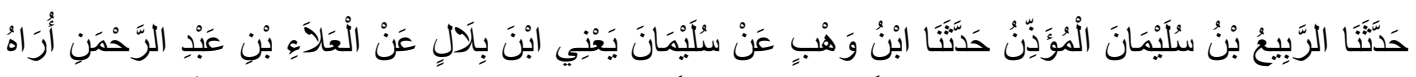

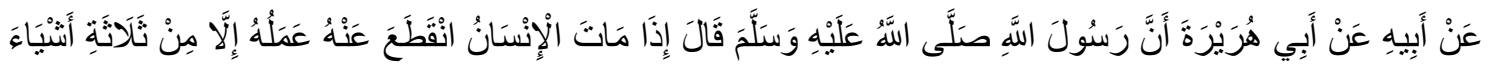

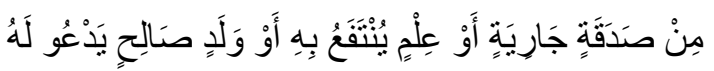

Artinya: Dari Abu Hurairah bahwa Rasulullah Saw. bersabda: Apabila seorang muslim meninggal, maka amalannya terputus kecuali dari tiga perkara: sedekah jariyah, ilmu yang bermanfaat, atau anak shalih yang mendoakannya." (HR. Muslim, Al Timidzi, Abu Daud, Ahmad, Al Nasa'i dan Al Darimi). ${ }^{2}$

Ketika menjadi orang tua hal yang harus diperhatikan ialah setiap anak membutuhkannya memasukkanya ke sekolah yang berkualitas, dan jika potensi itu tidak dikembangkan, tentu tidak masuk akal dalam kehidupan. Oleh karena itu perlu diperhatikan perkembangan setiap anak dan ini merupakan tindakan yang harus dilakukan sebagai bagian dari proses pendidikan dari usaha atau kegiatan tersebut.

\section{METODE}

Desain penelitian yang dipakai ialah penelitian (library research). yang mengkaji pustaka dan teknik pengumpulan data dengan cara melakukan literatur yang berkaitan dengan pembahasan serta informasi yang relevan terhadap pembahasan penelitian. Adapun

\footnotetext{
${ }^{1}$ Irawan, 2019. 'Potensi Manusia Dalam Perspektif Al-Qur'an', Islamika : Jurnal Agama, Pendidikan dan Sosial Budaya, 13(1) https://doi.org/10.33592/islamika.v13i1.153

${ }^{2}$ Kaharuddin. 2019. SANGAJI: Jurnal Pemikiran Syariah Dan Hukum 3 (1), 104-24. Accessed January 31, 2022. https://doi.org/https://doi.org/10.52266 /sangaji.v3i1.456.
} 
jenis penelitian pustaka menggunakan field research, dengan cara mendeskripsikan secara rinci dan berdasarkan fenomena-fenomena yang sedang terjadi.

\section{PEMBAHASAN}

\section{Hakikat Manusia}

Hakikat manusia dalam Islam ialah makhluk yang diciptakan. Dengan di ciptakannya manusia yang diberikan potensi atau kemampuan untuk hidup oleh Penciptanya (Allah). Ada beberapa mengenai konsep kemanusiaan. Menurut Abdul Aziz, Fitrah dapat dimanfaatkan untuk menggali potensi setiap seseorang sehingga dapat dimanfaatkan untuk mengikuti perkembangan dunia. Ketika sudah mengetahui potensi tersebut maka akan memungkinkan manusia untuk memprediksi semua berbagai masalah dalam kehidupan.

Fitrah merupakan keadaan yang telah diberikan sang pencipta kepada manusia sehingga mempunyai kehendak untuk mampu menerima hal yang benar. Secara fitrah, ${ }^{3}$ Manusia terkadang mempunyai hati kecil yang ingin mengunggkapkan kebenaran namun terkadang manusia tidak mampu menemukan kebenaran tersebut dikarenakan berbagai faktor eksogen.

Seperti pendapat dari Al-Ghazali memaknai secara luas fitrah adalah yang didapat sejak awal manusia dilahirkan, dengan memiliki potensi-potensi yang dimiliki setiap anak. ${ }^{4}$ Pertama, adanya kemauan untuk mempunyai keturunan yang baik, atau kemampuan untuk mau menerima pendidikan yang baik. Kedua, rasa ingin tahu untuk menggali esensi kebenaran. tersebut sehingga melatih kekuatan untuk berpikir. Ketiga, adanya dukungan dari biologis berupa keinginan, nafsu, dan kepribadian. Keempat, kekuatan dan kualitas manusia lainnya yang dapat dikembangkan dan dilatih.

Dengan adanya makna yang tersirat dalam kalimat fitrah tersebut dan juga terdapat dalam ayat tersebut, maka ada hadist shahih juga meriwayatkan dari Bukhori dan Muslim dari Abu Hurairah:

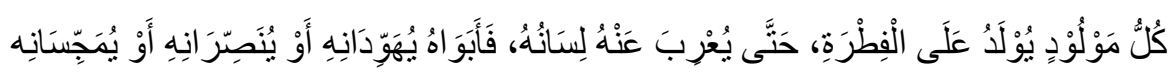

Artinya: Tidak ada satu anak pun yang dilahirkan kecuali dalam keadaan fitrah, maka kedua orang tuanyalah yang menyebabkannya menjadi Yahudi, Nasrani atau Majusi. (HR. Bukhori dan Muslim)

\footnotetext{
${ }^{3}$ Pransiska, Toni, 2017. 'Konsepsi Fitrah Manusia Dalam Perspektif Islam Dan Implikasinya Dalam Pendidikan Islam Kontemporer', Jurnal Ilmiah Didaktika, 17(1) https:/ / Doi.Org/10.22373/Jid.V17i1.1586

${ }^{4}$ Ghozali, A. 2020. KONSEP FITRAH MANUSIA (Studi Analisis di MTs Darel Fadilah Sidomulyo Pekanbaru). An-Nida', 42(2), 65-77. doi:http://dx.doi.org/10.24014/an-nida.v42i2.9363
} 
Maka yang menyebabkan adanya hadist di atas seperti yang dikatakan Aswad, berkata: "Aku datang kepada Rasulullah Saw. dan ikut berperang bersama beliau. Kami meraih kemenangan dalam perang itu: namun pada hari itu pembunuhan berlangsung terus termasuk menimpa anak-anak. Kejadian ini di laporkan kepada Nabi Saw. lalu beliau bersabda: "Keterlaluan, sampai hari ini mereka masih saling membunuh sehingga anakanak banyak yang terbunuh. Berkatalah seorang laki-laki, Ya Rasulullah, mereka adalah anak-anak dari orang musyrik. Rasulullah Saw bersabda: "Ketahuilah, sesungguhnya penopang kami adalah anak-anak orang musyrik itu. Jangan membunuh keturunan, jangan membunuh keturunan.”Kemudian beliau bersabda: Setiap anak dilahirkan dalam keadaan fitrah. Maka ia tetap dalam keadaan fitrahnya itu sampai lidahnya berbicara. Kedua orang tuanyalah yang menjadikannya sebagai Yahudi, Nasrani atau Majusi ${ }^{5}$.

Berdasarkan hadist di atas, kata fitrah berarti keinginan religius pada setiap orang. Keagamaan dalam konteks ini ialah Agama Islam. Bahkan, agama yang dianut seseorang anak sangat berkaitan berdasarkan agama yang dianut dari orang tuanya. Seperti anak yang dari orang tua Yahudi, Nasrani, atau magis bisa juga orang Yahudi, Nasrani, atau magis menurut hadist di atas. Hal ini merupakan bahwa karakter religius pada setiap anak sangat tergantung pada lingkungan dan proses pendidikan yang diberikan kepada mereka, terutama pendidikan orang tuanya. ${ }^{6}$ Memberikan perhatikan dapat dilihat dari latar belakang dari anak secara alami sehingga akan menjadikan kegiatan yang diajarkan berdasarkan pada keinginan, bakat dan kemauan anak menjadi menarik dan bergairah. Oleh karena itu, dalam pendidikan Islam mempunyai tanggung jawab dengan memelihara dan memperluas menjadi perantara terwujudnya segala keinginan anak dan terlaksananya transformasi nilai sosial budaya mereka dengan ruh Islami.

\section{Potensi Anak Dalam Pendidikan Islam}

Pendidikan mempunyai makna, secara bahasa kata pendidikan, kata ini berarti seperti "didik" dengan awalan "pen" dan berakhiran "kan". Pada awalnya kata pendidikan tersebut diambil dari bahasa Yunani, paedagogie. Ini berarti sesuatu seperti mengajar anak-anak. Jika diterjemahkan ke bahasa Inggris sebagai pendidikan. Ini merupakan memeberikan pengembangan atau konseling. Di dalam bahasa Arab, pendidikan juga di istilahkan atau di artikan sebagai tarbiyah yang berarti pendidikan.

Makna Agama berasal dari bahasa sansekerta. Artinya, "a" yang artinya "tidak" dan "gama" berarti kekacauan. Oleh karena itu, agama tidak berarti kakacauan dalam bahasa atau teratur dalam bahasa yang sederhana. Agama, di sisi lain, adalah aturan yang mengatur

\footnotetext{
${ }^{5}$ Aisyah, S. (2019). Pendidikan Fithrah dalam Perspektif Hadist (Studi tentang Fithrah Anak Usia 7-12 Tahun). Al-Adzka: Jurnal Ilmiah Pendidikan Guru Madrasah Ibtidaiyah, 9(1), 51 - 64. doi:http://dx.doi.org/10.18592/ aladzkapgmi.v9i1.3007

${ }^{6}$ Arham Junaidi Firman, Paradigma Hasan Langgulung Tentang Konsep Fitrah Dalam Pendidikan Islam, 2017, h. 43
} 
kondisi manusia dan sesuatu yang supernatural (tidak terlihat) tentang kepribadian dan koeksistensi sosial. Oleh karena itu, jika digabungkan dengan pendidikan, agama, dan Islam, maka pendidikan agama Islam adalah hikmah untuk membimbing, mengajar, melatih, membina, dan melaksanakan segala ajaran Islam yang syar'i sesuai dengan ajaran Islam.

Ahmad Tafsir berpendapat kalau Fitrah dapat secara bersamaan muncul seperti sikap baik dan buruk tampak terlihat, dan bisa juga menjadi Muslim dan musyrik, Fitrah di sini dapat diartikan sebagai orang yang mempunyai agama dan orang yang tidak mempunyai agama. Arti dari fitrah yaitu berupa potensi lebih tepatnya bila yang dimaksud dengan potensi batin seseorang adalah sebagai berikut: pemikiran, ruh, nafsu, qalb, fuad dan lainlain ${ }^{7}$. Maka bisa disebut dengan fitrah munazzalah, yang berarti potensi yang sudah siap untuk dikembangkan dikarenkana setiap potensi anak sejak dini masih bersih tanpa goresan sehingga sudah bias dikembangankan apapun itu, sumber bimbingan dan arahan yang sangat berpengaruh dan salah satunya faktor seperti lingkungan. Perkembangan fitrah khalqiyyah mempunyai kaitan dengan pengembangan fitrah munazzalah. Makna yang sudah terkonsep pada ajaran Islam yang melihat manusia tetap manusia, berbeda dengan binatang sebab manusia diberikan derajat yang lebih tinggi, mempunyai sifat tanggung jawab berdasarkan yang diperbuat, serta memikul amanah yang cukup berat. Setiap perbuatan atau karakter manusia masih dianggap sebagai makhluk terbaik ciptaan Allah, yang tidak diakui sebagai binatang.

Menurut Al-Ghazali, manusia terdiri dari komponen jiwa dan raga, dan menurut teori ini manusia adalah individu dengan komponen jasmani dan rohani. Kedua unsur ini tidak dapat dipisahkan, namun yang terpenting adalah unsur spiritual. Secara spiritual, ada beberapa unsur yang memaknai jiwa yaitu, hati, ruh, nafsu (hawa/ syahwat), serta pemikiran. ${ }^{8}$

Hati mempunyai dua bagian, unsur pertama yaitu kajian yang bersifat terbuka dan bersifat terkhusus. Pada kajian secara terbuka, hati yang merupakan daging yang terletak tepat disebelah kiri dari dada, yang berbentuk seperti buah sanubari. Sedangkan dalam unsur sederhana hati yang mempunyai sifat lembut yang bertindak dengan sifat lemah lembut, bijaksana dan penuh kasih sayang. Itu seperti sepotong daging yang mulia yang terdiri dari mulkiyah dan musyahadah dari semua sikap dan kekuatan Tuhan. Ruh (nyawa) memiliki makna, pertama, secara fisik ruh ada pada badan, banyaknya karunia kehidupan berupa, perasaan, penglihatan, pendengaran dan penciuman yang diberikan sang pencipta.

\footnotetext{
${ }^{7}$ RRubini, R. 2015. HADITS TARBAWI TENTANG POTENSI ANAK ( FITRAH ). AL-MANAR : Jurnal Komunikasi dan Pendidikan Islam, 4(2). doi:https://doi.org/10.36668/jal.v4i2.58

${ }^{8}$ Enung Asmaya, Hakikat Manusia Dalam Tasawuf Al-Ghazali', 2018, h. 35
} 
Nafsu adalah tempat untuk mengumpulkan kemarahan dan kekuatan serta keinginan setiap orang. Berdasarkan kualitas, nafsu dapat dibagi menjadi tiga yaitu, Pertama yaitu Nafsu mutmainnah yang menentang dengan nafsu syahwat, jenis nafsu ini yaitu tenang dan damai. Kedua, nafsu lawwamah yang berarti nafsu yang selalu memiliki sifat menyesali, nafsu ini ialah yang bisa mangajak di balik nafsu syahwat dan sejenisnya. Ketiga, Nafsu alamarah yaitu keinganan untuk melakukan kejahatan, yang selalu mengikuti keinginan dari syahwat (hawa nafs) yang memiliki keinginan untuk membentuk jiwa-jiwa perusak.

Ada beberapa tanggung jawab yang di tanggung orangtua salah satunya yaitu memberikan pendidikan Islam kepada anak yaitu dengan mengajarkan pendidikan shalat, sebagaimana dalam hadist:

$$
\text { حدثنا مؤمل بن هشام - يعنى اليشكرى - حدثنا إسماعيل عن سوار أبى حمزة - قال أبو داود وهو سوار بن }
$$

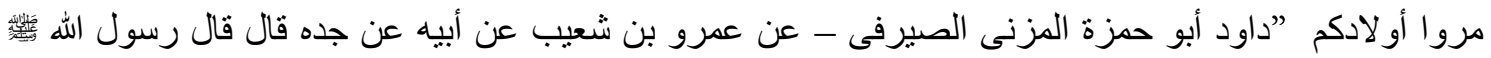

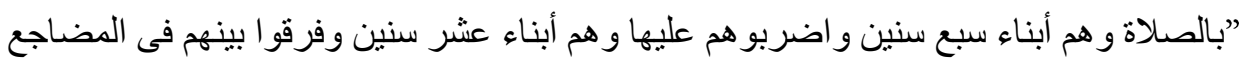

Artinya: Telah menceritakan kepada kami Mu'ammal bin Hisyam Al Yasykuri telah menceritakan kepada kami Isma'il dari Sawwar Abu Hamzah berkata Abu Dawud: Dia adalah Sawwar bin Dawud Abu Hamzah Al Muzani Ash Shairafi dari Amru bin Syu'aib dari Ayahnya dari Kakeknya dia berkata: Rasulullah shallallahu 'alaihi wa sallam bersabda: "Perintahkanlah anak-anak kalian untuk melaksanakan shalat apabila sudah mencapai umur tujuh tahun, dan apabila sudah mencapai umur sepuluh tahun maka pukullah dia apabila tidak melaksanakannya, dan pisahkanlah mereka dalam tempat tidurnya." (HR Abu Daud).

Hadist ini berbentuk anjuran agar orangtua mendorong anaknya supaya melaksanakan ibadaha shalat dan membedakan dari tempat tidur mereka. Pada kenyataannya, ini tidak lebih dari banyak nilai yang terkait dengan perintah, kebijaksanaan, dalam memberikan pendidikan dan karakter anak, yang dibentuk dari isi kandungan hadist tersebut. Hadist ini tentunya memiliki makna perintah kepada setiap orang tua. Dikarenakan orang tua adalah orang pertama yang dimintai pertanggungjawaban oleh Allah atas anak-anaknya. Selain sebagai penanggung jawab, orang tua merupakan pendidik anak pertama dalam kehidupan.baik itu sudah lahir kedunia, tetapi sejak di dalam kandungan, anak tanpa sadar mendengar, melihat, dan mempelajari semua perbuatan orang tuanya, terutama ibunya, seperti yang di jelakan sebelumnya. Oleh karena itu, Islam memerlukan persiapan terlebih dahulu untuk keberhasilan pendidikan anak. Hal ini dinilai sangat mendesak karena semuanya membutuhkan proses.

Pendapat dari Jalaluddin, secara keseluruhan ada beberapa potensi utama yang diberikan Allah secara alamiyah yang terletak pada setiap manusia, (1) kemapuan naluriyah (hidayat al-ghariziyyat) yaitu adanya pengaruh primer yang mempunyai manfaat dengan 
memelihara kesempurnaam untuk kelanjutan kehidupannya. (2) kemampuan indrawi (hidayat al-hissiyat), mempunyai harapan untuk mengenal dunia luar. (3) kemapuan intelektual (hidayat al-aqliyyat), mempunyai kemampuan manusia untuk menanggapi makna-makna, yang bersifat abstrak. Dan dapat menganalisis diaman perbedaan baik itu salah maupun baik (4) kemapuan religius (hidayat al-diniyyat), kemauan untuk terus berusaha dan patuh akan perintah akan yang maha kuasa.

Sedangkan H. M. Arifin berpendapat, ada beberapa komponen psikologi dalam fitrah tersebut, yaitu; (1) kemampuan dasar untuk keagamaan (al-din al-qayyimat), (2) mawabih (bakat) dan qabliyyat (kecenderungan); (3) naluri dan kewahyuan (revilasi). Menurut Hasan langgulung, fitrah dapat dilihat dari dua bagian, yakni; pertama, dalam pandangan naluriah tentang sifat manusia atau sifat-sifat tuhan yang menjadi sumber daya manusia dari dalam dirinya sendiri. Kedua, tentang wahyu yang diturunkan Allah kepada Nabi-nya; (4) Pengetahuan dasar yang bukan agama umum tidak terbatas pada Islam; (5) Komponen psikologis apa pun dalam esensi ini karena fitrah didefinisikan sebagai keadaan pikiran yang bersih, murni, menerima, terbuka terhadap pengaruh luar termasuk didikan. ${ }^{9}$

\section{Upaya Mendidik Anak dalam Islam}

Setiap orang tua telah mempunyai usaha dan cara agar bisa meberikan hal yang terbaik untuk anaknya, baik itu untuk pendidikan. Dengan melaksanakan perannya dengan baik sehingga anak bisa berkembang optimal berdasarkan karakter yang di milikinya.

Secara keseluruhan yang berkaitan dengan pendidikan terhadap kepercayaan bisa temukan dari pesan-pesan Rasulullah SAW. Dari pesan-pesan tersebut maka akan ditemui dasar dari iman serta rukun Islam pada patut diajarkan kepada anak. Berikut ada beberapa petunjuk dari pesan Rasulullah SAW:

\section{Mengajarkan anak kalimat Tauhid}

"Bacalah kepada anak-anak kamu kalimat pertama dengan la ilaha illAllah (tidak ada tuhan selain Allah). Maksud dari hadits ini adalah agar kalimat tauhid dan syi'ar masuk Islam itu merupakan suatu yang pertama masuk kedalam pendengaran anak, kalimat yang diucapkan oleh lisanya dan lafazh pertama yang difahami anak.

1. Memberi Nama yang mempunyai arti yang baik

"Kewajiban orang tua terhadap anaknya adalah memberi nama yang baik, memberi tempat tinggal yang baik, dan mengajari sopan santun.” Rasulullah SAW diketahui telah memberi perhatian yang sangat besar terhadap masalah nama.kapan saja beliau menjumpai nama yang tidak menarik (patut) dan tak berarti, beliau mengubahnya dan memilih

\footnotetext{
${ }^{9}$ Kaharuddin, Konsep Pendidikan Agama dan Karakter Anak., h. 105
} 
beberapa nama yang pantas. Beliau tak akan sungkan untuk mengganti nama anak apabila nama tersebut tidak mempunyai makna yang baik.

Memberikan nama yang baik serta mempunyai arti yang baik pula bagi anak merupakan pendidikan awal terhadap anak ada yang bilang "siapa namanya". Islam mengungkapkan bahwa ini tidak selalu benar dan mengajarkan bahwa nama untuk anak laki-laki adalah doa. Dengan memberikan nama yang baik, diharapkan anak kita bisa mengharumkan namanya. Akhirnya setelah kita memberikan nama yang baik dan memeliharanya dengan baik, terkadang akhlak anak tidak sesuai dengan yang kita inginkan, maka kembalilah kepada Allah SWT. Nama yang baik dengan moral yang baik, itu yang diharapkan.

\section{Memberikan pendidikan di mulai dari melaksanakan shalat, membedakan kamar anak yang laki-laki dan anak perempuan.}

Agama Islam juga menganjurkan untuk melatih menggunakan "hijab" sejak usia dini, apabila anak sudah memasuki usia tujuh tahun sudah seharusnya tempat tidur harus dipisahkan. Islam menyeruh untuk melatih anak menggunakan 'hijab' sejak usia dini. Bahkan jika bersaudara kandung mereka harus berpisah ketika mereka berusia tujuh tahun. Rasulullah Saw berfirman, "Suruhlah anak-anakmu shalat bila berumur tujuh tahun dan gunakan pukulan jika mereka sudah berumur sepuluh tahun dan pisahlah tempat tidur mereka (putra-putri).” Dengan kata lain, semestinya membesarkan dan mendo'akan seorang anak dimulai ketika anak sudah masuk tujuh tahun. jikalau berumur sepuluh tahun namun tak mau mengerjakan sholat, kemudian boleh memberikan pukulan ringan yang bisa membuatnya sadar dan patuh, makna pukulan disini bukan berarti memukul dengan cara menyakitinya dan memukul yang memberikan bekas.

2. Memberikan ajaran kepada anak untuk mengidolakan sang Rasul, Ahli Baitnya Dan Membaca Al-Quran. Ath-Tabrani meriwayatkan dari Ali ra. Bahwa Nabi bersabda, "Didiklah anak-anak kamu pada tiga perkara: mencintai Nabimu, mencintai ahli baitnya dan membaca al-Quran sebab orang- orang yang memelihara al-Quran itu berada dalam lindungan singgasana Allah pada hari tidak ada perlindungan selain dari pada perlindunga-Nya beserta Nabi-Nya dan orangorang yang suci."

Perlu adanya menceritakan kepada mereka bagaimana cara-cara berperang pada masa Rasulullah SAW. Sebuah perjalanan melalui kehidupan para sahabat, kepribadian para pemimpin besar, dan pertempuran sejarah yang mengerikan. ${ }^{10}$ Dari hadist tersebut dapat dipahami supaya anak-anak bisa meneladani orang yang hidup terdahulu serta mengetahui bagaimana awal perjalanannya, baik itu secara gerakan, kepahlawana dan jihat mereka.

\footnotetext{
${ }^{10}$ Muhammad Fatkurrochman, Anak (Telaah Pendapat Surat Lukman Ayat13), 2017.
} 
Disamping itu agar anak-anak terikat pada sejarah, baik perasaan maupun kejayaan, termasuk dalam kerikatan mereka terhadap Al-quran.

\section{Pendapat Para Ahli Mengenai Dasar Fitrah Manusia}

Penafsiran para pakar pendidikan Islam tentang fitrah di dalam Al-Qur'an membawa mempengaruh hingga menyebabkan adanya teori fitrah dalam mengakaji pendidikan. Menurut Yasien Mohamed yang dikutip Maragustam, bahwa pengertian fitrah manusia dan perkembangannya dapat dibagi menjadi empat kategori: fatalis-pasif, netral-pasif, positif-aktif dan dualis-aktif.. (Maragustam Siregar, 2010)

\section{Teori Fatalis-Pasif}

Pada teori Fatalis-pasif percaya pada dasarnya semua manusia mempunyai sifat baik atau jahat sudah kehendak dari Allah. Ketetapan ini semacam yang telah dibuat untuk seluruhnya atau sudah rencana Allah. Karena setiap individu terikat oleh pedoman yang diberikan Tuhan, kemampuan manusia untuk berkembang menjadi pasif. Berbicara tentang kebaikan dan kejahatan manusia tentu tidak akan bisa bebas dari filsafat moral, juga tidak akan terlepas dari pengertian nilai-nilai kemanusiaan. Mengingat posisinya sebagai isu pertama filsafat moral, studi nilai menjadi sangat penting. Selain itu, penelitian nilai adalah studi yang menyentuh pertanyaan-pertanyaan esensial filsafat moral. Pertanyaan yang selalu muncul dalam penelitian ini adalah apa yang "baik" dan "buruk". Sebagai anggota kelompok non-naturalis.

Immanuel Kant mewakili prinsip otonomi dan heteronomi dalam menentukan moralitas. Otonomi ialah bentuk otonomi kehendak (the autonomy of the will). Seseorang menjadi bertekad untuk membiasakan dengan tindakan bermoral dan melakukan tindakan moral berdasarkan kehendak yang tidak ditentukan oleh kepentingan atau kecenderungan lain. Disebut heteronomi atau asas heteronomi (heteronomy), menyatakan bahwa seseorang berperilaku moral karena dipengaruhi oleh berbagai hal di luar kehendak manusia. Pada prinsip ini, kehendak (the will), tidak serta merta menjadikan dirinya sebagai sebuah ketetapan (the law), tetapi sebuah ketetapan (the law) diberikan oleh objek tertentu melalui kaitannya dengan kehendak (the will).

\section{Teori Netral-Pasif}

Dalam Teori netral-pasif menyatakan bahwa ketika seorang anak dilahirkan, ia dalam keadaan murni, sempurna, seperti dalam keadaan kosong apa adanya, belum memiliki iman atau kesadaran, baik atau buruk. Teori ini sama dengan teori Tabularase John Locke. Bakat yang dimiliki setiap anak dapat berkembang menjadi pasif dan sangat bergantung dari kehidupan yang ada di lingkungan sekitar, terutama pendidikan. Dengan begitu pada dasarnya setiap anak mempunyai sifat netral di mana tidak ada yang baik atau jahat. 
Tindakannya di dunia luar tidak efektif. Yang membentuk kepribadian dan watak seseorang, baik atau tidaknya, tergantung pada lingkungan alamnya. (Maragustam Siregar: 2010).

Salah satu tokoh dalam teori ini adalah Ibnu Abd al-Barr. Ia berpendapat bahwa setiap orang berpotensi menjadi baik dan aktif bila dipengaruhi dari luar, terutama oleh orang tua yang mendidik mereka seperti itu. Di sisi lain, hal itu berpotensi menjadi buruk ketika nilai-nilai kebenaran yang ada di lingkungan, baik dan adil kepada anak-anak, diabaikan, atau ketika anak-anak diajarkan benar-benar buruk dan buruk. Doktrin adalah penentu karakternya yang paling kuat dan paling kuat. Entah itu pintar atau bodoh, kreatif atau kuno. Pandangan ini mengambil argumen dari Al-Nahl (16):78.

\section{Teori Positif-Aktif}

Teori positif-aktif berbedapat pada awalnya kemanusiaan adalah baik sejak lahirpun dalam keadaan baik. Sedangkan kejahatan datangnya secara kebetulan. Kemampuan perkembangan setiap anak bersifat aktif. Salah satunya adalah sumber yang bisa dibangun dari dalam setiap anak. Pendukung teori ini adalah Ibnu Taimiyah, Ibnu Qayyim alJauziyah, Muhammad Ali al-Shobuni, Mufti Muhammad Syafi'i, Ismail Raji al-Faruqi, Mohammad Asad, Syah Waliyullah.

Ibnu Taimiyah berpendapat bahwa semua anak yang lahir dalam keadaan Fitrah. Dengan kata lain, lahir dengan keadaan baik pembawaanya namun lingkungan sosial yang bisa membuat setiap anak bisa menjadi menyimpang dari keadaan ini. Hakikat pada manusia tidak hanya memiliki pengetahuannya sendiri tentang Allah SWT, tetapi juga kecintaannya kepada-Nya dan keinginan untuk ikhlas menjalankan ajaran agama sebagai hanif sejati, seperti tersebut dalam surat al-Rum: 30.45 Ibnu taimiyah juga memberikan tanggapan atas pandangan Ibnu Abd al-Barr menegaskan bahwa fitrah bukan hanya kemungkinan positif untuk terbangun dari luar, tetapi juga merupakan sumber kebangkitan dari dalam. Dalam perkembangan selanjutnya, M. Quraish Shihab kemungkinan besar akan menerima tren positif ini. Menurutnya, kodrat manusia adalah suatu peristiwa sejak awal, atau pada dasarnya lahir dari lahir. Para ulama memahaminya dengan tauhid. Ia menyatakan bahwa kodrat manusia adalah kemungkinan manusia untuk menjadi religius dan bertauhid kepada Allah Swt. (Shihab: 2007)

Muchlis Usman menyatakan bahwa ayat atau hadist yang berkaitan dengan fitrah setiap orang, secara menyeluruh telah menunjukkan arti esensi dan eksistensi manusia diciptakan, sebagaimana manusia diciptakan sebagai hamba dan pemimpin oleh Allah SWT. Setiap orang sudah diberikan jasmani yang dilengkapi mempunyai akal, sehingga bisa berpikir untuk berbuat dan bertindak semata-mata sebagai hamba dan pemimpin yang dikendaki Allah Swt di muka bumi ini. Ketika tindakan dan perbuatan manusia itu 
menyimpang dari eksistensinya sebagai abdi dan khalifah Allah, apabila manusia tidak bisa mengemban amanah yang diberikan Allah Swt, ia akan tetap menjadi manusia apabila manusia tersebut melakukan penyimpangan dari fitrahnya. Dan ketika manusia melakukan tindakan dan perbuatan sangat baik seperti malaikat, tidaklah bisa mengubahnya menjadi malaikat. Sementara itu, dalam perkembangan pradaban Islam, makna fitrah manusia mengalami perkembangan.

\section{Teori Dualis-Aktif}

Pada teori ini berpendapat bahwa pada dasarnya manusia mempunyai sifat bawaan yang ganda di satu sisi, itu terlihat bagus, di sisi lain-buruk. Metode kedua adalah dinamis dan konsisten. Kaum dualistik sekarang mengklaim bahwa manusia diciptakan dari dua hal: tubuh (Nafs) dan jiwa (roh), bumi dan roh. Masing-masing dari dua faktor ini adalah yang pertama di mana kehidupan tidak independen dari yang lain. Jadi roh tidak berasal dari tubuh, tetapi tubuh tidak berasal dari roh.

Salah satu filsuf Islam, yaitu Ibnu Sina, mengartikan bahwa akal sama dengan jiwa (Nafs). Menurutnya, jiwa adalah kesempurnaan pertama. Karena menjadikan benih (jin) sempurna dan menjadi manusia yang sesungguhnya. Artinya, jiwa adalah kesempurnaan pertama pada tubuh. Hal ini karena jasad itu sendiri merupakan syarat dari definisi jiwa. Ia dapat disebut jiwa bila berada dalam tubuh yang sebenarnya dengan alat tertentu, perilaku yang berbeda dimediasi oleh anggota tubuh yang berbeda yang memenuhi dari kejiwaannya.

Jiwa dapat dibagi menjdi tiga jenis bagian, sepeeti yang di sampaikan Ibnu Sina juga membagi daya antara jiwa (ruh) yang dapat saling berkaitan yaitu: (Ibnu Sina: 1952)

a.

Jiwa (ruh) seperti tanaman, yang meliputi kemapuan yang ada pada dri anak, hewan serta tanaman.

b. Jiwa (ruh) sebagai hewan, yang berkaitan dengan semua kemampuan yang terdapat pada manusia dan hewan.

c. Manusia memiliki kekuatan jiwa mental khusus. Roh ini bekerja pada intelek. Ibnu Sina menjelaskan bahwa ini adalah kesempurnaan pertama dari tubuh nyata mekanis, yang di satu sisi bertindak dengan cara yang berbeda dalam kaitannya dengan kemampuan logis dan mental, tetapi di sisi lain melihat segala sesuatu yang lain.

Menurut al-Ghazali, ruh terbagi menjadi dua; pertama yaitu disebut ruh hewani, yakni jauhar yang bersifat halus dan lembut yang terdapat pada rongga hati jasmani dan merupakan sumber kehidupan, perasaan, gerak, dan penglihatan yang dihubungkan dengan anggota tubuh seperti menghubungkan cahaya yang menerangi sebuah ruangan. 
Kedua, yaitu nafs natiqah, yakni memungkinkan manusia mengetahui segala hakekat yang ada. Al-Ghazali berkesimpulan bahwa hubungan ruh dengan jasad merupakan hubungan yang saling mempengaruhi. (Dewan Redaksi: 1993).

Ahmad Tafsir merupakan yang masuk dalam kelompok ganda. Dia mengatakan bahwa fitrah yang disebutkan dalam hadist adalah fitrah, yaitu bisa baik dan jahat sekaligus, bisa muslim dan musyrik. Kemungkinan potensi ini tidak berubah. Dengan kata lain, kecenderungan untuk berbuat baik dan jahat secara bersamaan tidak dapat diubah oleh Tuhan. Ahmad Tafsir menyandarkan pada hadist. ${ }^{11}$

Pendapat dari Syari'ati, seperti yang dikutip oleh Mohammad dan Maragustam. Hal ini dipadukan dengan pikiran Allah SWT sebagai self-educator. Dengan cara ini, manusia merupakan ciptaan yang mempunyai dua dimensi dengan sifat dobel, tidak hanya dari dua kekuatan yang berbeda tetapi juga memiliki kekuatan yang saling berlawanan.

\section{Cara Menggali Potensi yang dimiliki anak dalam Islam}

Anak yang mempunyai potensi sangat bergantung kepada orangtua dimana ketika sudah mempunyai bakat/potensi tetapi jika tidak di digali atau diasah maka potensi itu tidak akan berkembang oleh sebab itu perlunya orangtua untuk menggali dan mengenali potensi yang dimiliki anak, bahkan sejak dini sudah bisa diterapkan dengan beberapa cara sebagai berikut:

\section{Memberikan perilaku khusus}

Pemberian tindakan khusus disini bukan berarti anak yang lainnya tidak dipedulikan, tetapi khusus disini yaitu orangtua memberikan dukungan dan berbagai stimulus. Sehingga ketika sudah diketahui bakatnya orangtua bisa mengarahkannya.

\section{Keadaan lingkungan sekitar}

Suasana lingkungan sekitar juga merupakan bisa menjadi faktor yang sangat berpengaruh terhadap perkembangan anak, keluarga menjadi salah satu faktor yang terdekat anak dimasa pertumbuhan, oleh karna itu orangtua harus bisa menjaga segala perbuatan, perkataan yang bisa membuat anak menirunya.

\section{Memberikan pendamping yang berbakat}

Anak yang sudah mempunyai bakat cenderung mempunyai pola pikir yang lebih baju dan daya tangakap yang cepat, keseringan dimasa perkembangan anak akan banyak pertanyaan-pertanyaan yang muncul, dan sebgai orangtua harus bisa menjawab pertanyaan tersebut dengan Bahasa yang di pahami.

\footnotetext{
${ }^{11}$ Syarifah Ismail, 'Tinjauan Filosofis Fitrah Manusia Dalam Pendidikan Islam, 2013, h. 62
} 


\section{Pemberian tugas yang menarik}

Berikan rasa nyaman ketika anak memperlajari sesuatu, jangan sampai anak menjadi bosan, oleh karena itu perlunya orangtua menjadi kreatif. Ada banyak sekarang bahanbahan yang bisa dijadikan sebagai media pembelajaran, tidak harus mahal dan bisa di dapat di sekitarnya. ${ }^{12}$

\section{PENUTUP}

Setiap anak ditempatkan dalam keadaan fitrah. Dalam arti fisik, ini berarti setiap orangtua mempunyai cara tersendiri untuk merawat anakanya dan pasti setiap orangtua juga mempunyai kekurang dalam mendidik buah hatinya, tetapi mereka dianggap sebagai kertas kosong yang belum ternodai, John Lock, atau tidak memiliki daya seperti pandangannya jabariyah. Hal ini disebabkan karena setiap anak sudah mempunyai kemampuannya masing-masing, yang dapat digunakan untuk menciptakan daya nalar, mental, atau psikisnya dengan berbagai ragam dan levelnya.

Dari keterangan Al-qur'an, Hadist, maupun pemikiran para ulama dan para mufassir, dari semua pendapat tersebut hampir semuanya berpendapat bahwa terdapat fitrah yang sudah dimiliki mulai anak lahir ke dunia. Namun eksistensi fitrah bisa berubah jikalau anak sudah berkembang sampai dewasa.

Orangtua menjadi peran utama yang akan memberikan pendidikan dan juga sebagai sarana yang bisa menumbuhkembangkan potensi dan kemampuan pada setiap anak sesuai dengan fitrah penciptaannya. anak mampu memberikan peran dan dapat membuat manfaat dari beragam aspek kehidupan baik untuk dirinya maupun bagi orang lain. Pada dasarnya, tujuan dari pendidikan adalah ingin mengembangkan dan membina perilaku dan kebiasaan setiap tingkahlaku anak sehingga anak akan siap hidup terampil serta bertanggung jawab dengan menghadapai tantangan situasi hidup secara manusiawi.

Jalaluddin berpendapat, Secara umum, ada banyak jenis kemampuan utama yang diberikan Allah SWT kepadanya, yaitu, pertama potensi naluriyah (hidayat al-ghariziyyat), kedua, kemampuan indrawi (hidayat al-hissiyat), ketiga kemampuan pada akal (hidayat alaqliyyat), keempat kemampuan keagamaan (hidayat al-diniyyat).

Cara mendidik anak dalam Islam yaitu; (1) Mengajarkan anak kalimat Tauhid, (2) Menyematkan nama-nama yang bermakana kebaikan, (3) Mendorong anak untuk sholat dan sediakan kamar tidur terpisah untuk anak laki-laki dan perempuan, (4) Membimbing agar anak Mencintai Rasul dan mengidolakan para Rasul, Ahli Baitnya dan Membaca AlQuran.

\footnotetext{
${ }^{12}$ Yumnah, Siti. 2016. Kecerdasan Anak Dalam Pengenalan Potensi Diri, Jurnal Studi Islam,11(2).
} 
Berbicara mengenai hakikat fitrah yang terdapat pada Al-Quran menyebabkan lahirnya teori alam dalam pendidikan, memahami bagaimana kemampuan bawaan manusia (fitrah) dapat berkembang ada empat yaitu: fatalis-pasif, netral-pasif, positifaktif dan dualis-aktif.

Maka dari itu, setiap proses pendidikan perlu adanya menanamkan kebajikan bawaan yang aktif secara alami dan dapat di ajarkan sejak usia dini. Disinilah pentingnya peran orangtua dan keluaraga untuk pendidikan anaknya. Bagaimanapun, setiap anak akan bisa menjadi sebaik-baiknya (khaerah ummah). Wallahu a'lam bi al-shawab.

\section{DAFTAR PUSTAKA}

Aisyah, S. (2019). Pendidikan Fithrah dalam Perspektif Hadist (Studi tentang Fithrah Anak Usia 7-12 Tahun). Al-Adzka: Jurnal Ilmiah Pendidikan Guru Madrasah Ibtidaiyah, 9(1), 51 - 64. doi:http://dx.doi.org/10.18592/aladzkapgmi.v9i1.3007

Asmaya, Enung. 2018. 'Hakikat Manusia Dalam Tasawuf Al-Ghazali', KOMUNIKA: Jurnal
Dakwah
Dan
Komunikasi,
12.1
(2018),

Https://Doi.Org/10.24090/Komunika.V12i1.1377.

Fatkurrochman, 2017. Muhammad, Anak (Telaah Pendapat Surat Lukman Ayat 13).

Firman, Arham Junaidi, 'Paradigma Hasan Langgulung Tentang Konsep Fitrah Dalam Pendidikan Islam', Jurnal Pendidikan Islam UHAMKA, 8.2.

Ghozali, A. 2020. KONSEP FITRAH MANUSIA (Studi Analisis di MTs Darel Fadilah Sidomulyo Pekanbaru). An-Nida', 42(2), 65-77. doi:http://dx.doi.org/10.24014/annida.v42i2.9363

Irawan, 2019. 'Potensi Manusia Dalam Perspektif Al-Qur'an', Islamika : Jurnal Agama, Pendidikan dan Sosial Budaya, 13(1) https://doi.org/10.33592/islamika.v13i1.153

Ismail, S. 2013. Tinjauan Filosofis Pengembangan Fitrah Manusia dalam Pendidikan Islam. At-Ta'dib, 8(2). doi:http://dx.doi.org/10.21111/at-tadib.v8i2.510.

Kaharuddin, Kaharuddin. 2019. SANGAJI: Jurnal Pemikiran Syariah Dan Hukum 3 (1), 10424. Accessed January 31, 2022. https://doi.org/https://doi.org/10.52266 /sangaji.v3i1.456.

Pransiska, Toni, 2017. 'Konsepsi Fitrah Manusia Dalam Perspektif Islam Dan Implikasinya Dalam Pendidikan Islam Kontemporer', Jurnal Ilmiah Didaktika, 17(1) .https://Doi.Org/10.22373/Jid.V17i1.1586

Rubini, R. 2015. HADITS TARBAWI TENTANG POTENSI ANAK ( FITRAH ). ALMANAR : Jurnal Komunikasi dan Pendidikan Islam, 4(2). doi:https://doi.org/10.36668/jal.v4i2.58

Yumnah, Siti. 2016. Kecerdasan Anak Dalam Pengenalan Potensi Diri, Jurnal Studi Islam,11(2). 